\title{
Household Level Analysis Of Food Insecurity And Coping Strategies: Evidence From ENUGU State, Nigeria.
}

\author{
C. N. Onunka \\ Department of Agricultural Economics, University of Nigeria, Nsukka \\ Food Security and Sustainable Agriculture, \\ College of Life and Environmental Sciences, University of Exeter, EX4 4QD, UK \\ E. J. Ihemezie \\ Department of Agricultural Economics, \\ University of Nigeria, Nsukka \\ C. C. Olumba \\ Department of Agricultural Economics, Management and Extension, \\ Ebonyi State University, Nigeria
}

\begin{abstract}
The study analysed the strategies used by the rural households to cope with food insecurity in Udi local government area of Enugu state. Data were collected through household surveys using semi-structured questionnaires. Descriptive and inferential statistical tools were employed to analyse the data for the study. Households were grouped based on their food security status (food secure and food insecure). The study result showed that the two-group household differed significantly in some of their socio-economic characteristics. The study confirms that the coping strategies employed by the vulnerable households were not mutually exclusive, rather a mixed approach comprising multiple strategies were adopted to cushion food insecurity shocks. Furthermore, socioeconomic factors such as income $(p<0.01)$, marital status $(p<0.1)$ and educational level $(p<0.01)$ were found to negatively influence the number of coping strategy adopted by rural households while the dependency ratio $(p<0.01)$ was positively significant. Policy implications were drawn for education promotion, poverty alleviation programs and the creation of sustainable off-farm employment opportunities.
\end{abstract}

Keywords: food insecurity; coping strategies; rural households; Enugu state

\section{INTRODUCTION}

In the early 50s, Nigeria did not have to contend with the problem of food insecurity. Every region of the country was involved in the production of one or two major crops, whether food or cash crops and the country generally was relatively self-sufficient in food production. However, in the last recent decades and till present, the country is faced with the challenge of meeting the basic food needs of its population (Ojo and Adebayo, 2012). This food crisis in Nigeria has been partly blamed on the discovery of crude oil which has shifted the focus of the government away from the agricultural sector (Fasinmirin and Braga, 2009). Moreover, Ehui and Tsigas (2009) asserted that the food crisis in Nigeria is not unconnected with the fact that Nigeria's agriculture is mostly in small-scale and predominantly subsistence based, hence domestic produce fails to meet the food demands of the country's population. Consequently, food insecurity, malnutrition and poverty are realities in Nigeria especially among the poor and vulnerable rural farming households. Akinyele (2009) explains that Nigeria is nationally 
food insecure, providing estimates of the overall prevalence of stunting, wasting, and underweight at 42.0 percent, 9 percent and 25 percent, respectively.

In this light, achieving food security is currently both a fundamental objective and an expected outcome of development policies in Nigeria. Food security refers to a situation whereby individuals have access at all times to quality and sufficient food resources to maintain a healthy and active life (World Bank, 1986). On the other hand, food insecurity exists when there is constrained physical and economic access to secure sufficient quantities of nutritionally adequate food to allow individuals sustain an active and healthy living (Wolfe and Frongillo, 2001). Food insecurity comes with unpleasant conditions with consequences detrimental to human health, well-beingand productivity (Ifeoma and Agwu, 2014). Consequently, when faced with food insecurity, households device strategies to minimize the impact of food insecurity and as well as to stabilize their food access. Generally, households employ different coping strategies in the early stages of food insecurity, which however vary based on cultural and geographical differences (Maxwell, 2008) and as well as their social and economic resource endowment (Liwenga, 2003).

Literatures have identified that households are significantly more inclined to adopting multiple coping strategies when hit with food crisis (Farzana et al., 2017; Ehebhmen et al., 2017). However, the contexts that compel households to apply multiple coping strategies, are not particularly well defined. This paper is based on a cross-sectional data collected at the household level in Udi local government area to examine the coping behaviours of households and factors influencing the number of coping strategies employed. Understanding the implemented coping strategies at the household level is critical for formulating and implementing appropriate policy and design programs related to addressing the problem of food insecurity. The study result is expected to complement the current understanding of different coping strategies pertaining to food insecurity implemented by the rural Nigeria households.

The study seeks to i) describe the socio-economic characteristics of the households by their food security status, ii) analyse the extent of use of the coping strategies by the households; and iii) assess the socio-economic factors influencing the use of multiple coping strategies. 


\section{CONCEPTUAL FRAMEWORK}

Figure 1: Household socio-economic characeristics and food insecurity coping strategies

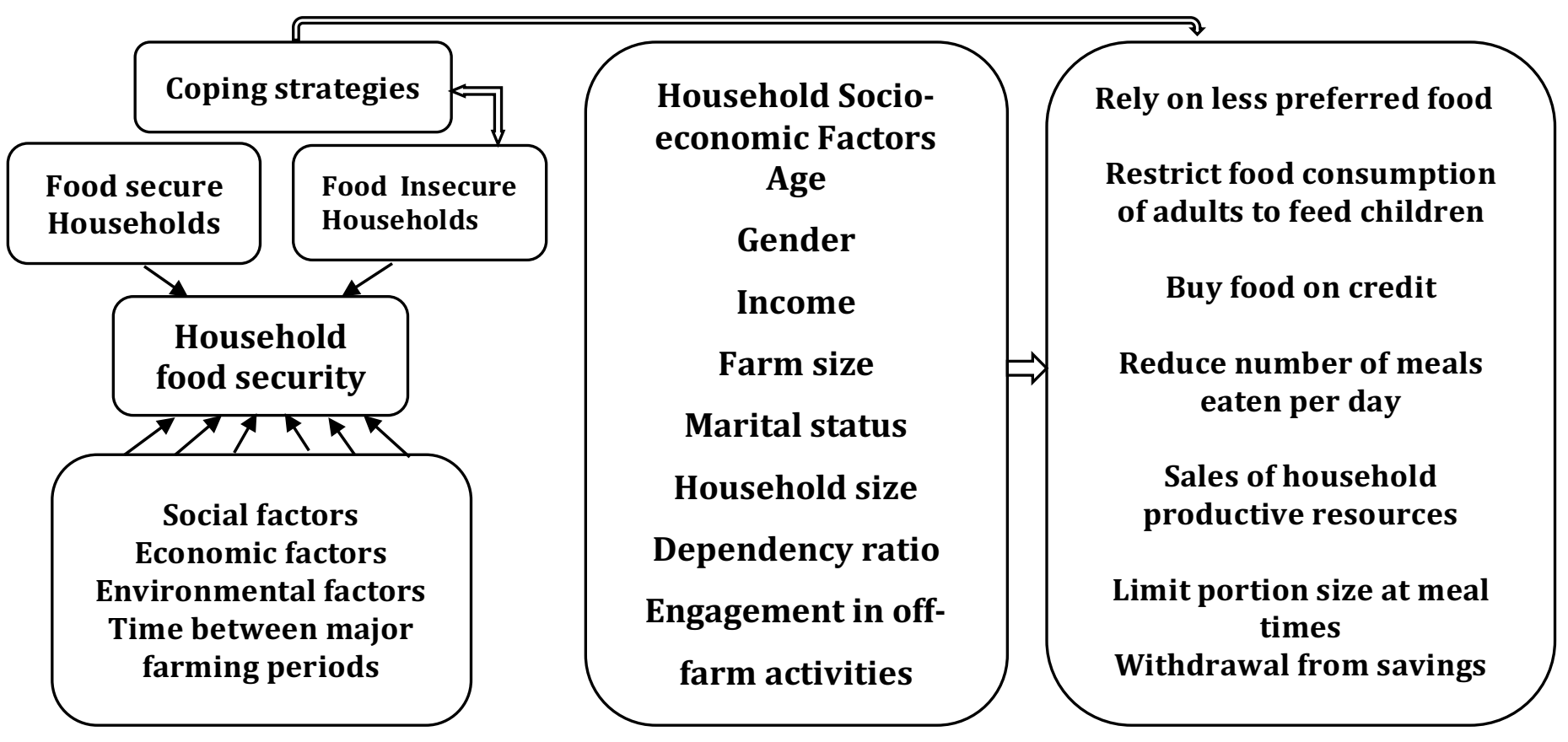

Analyst have emphasized the significance of household socio-economic factors, environment and climatic factors and time between major farming periods (harvesting and planting periods) to either positively or negatively influence on households' capability to afford and access their basic food and nutrition needs (Amaza et al. 2006; Edeh and Gyimah-Brempong, 2015; Kabubo-Mariara and Kabara, 2014). Depending on the effect of these factors household become food secure or food insecure. However, food insecure households reportedly exhibit a range of techniques to respond to the situation. The variety of techniques adopted by households is commonly referred to as coping strategies. Maxwell et al. (2000) defined coping strategies as the activities that people take to mitigate the effects of not having sufficient food to meet the household's dietary needs. Some coping strategies are positive means of overcoming food shortages, while some strategies are deemed negative and can permanently undermine household future food security. For example, when households modify their food consumption by reducing the number of meals per day or the quantity of food cooked, it is considered to have less impact on their future food security, thus are described as positive strategies. However, strategies such as selling household productive resources and reducing expenditures on basic services such as health and education have long-term detrimental effects on household food security (Ezeama at al., 2015), hence are termed negative. According to Farzana et al. (2017), depending on the severity of food insecurity household employ more than one strategy to cope with the situation. The study proposes that the number of coping strategies adopted by household is associated with household socio-economic characteristics; hence the nexus between the household socio-economic variables and the coping strategies in the framework.

\section{Study area}

\section{METHODOLOGY}

The research was carried out in Udi local government area (LGA) in Enugu state, Nigeria. The area is located between latitude $6^{\circ} 12^{\prime} \mathrm{N}$ and longitude $10^{\circ} 42^{\prime} \mathrm{N}$ of the equator and $7^{\circ} 28^{\prime} \mathrm{E}$ of the Greenwich Meridian. It has a total land area of 973.805 square kilometres. The population 
census held in 2006, puts the population of the Udi local government at 238,305, comprising 117,914 males and 120,391 females (National Population Commission, 2006). Owing to the endowment of good soil that supports agricultural production, the major economic activity of the people of Udi LGA includes subsistence farming (crop and livestock production) and palm wine tapping. Other common occupations however include civil service and small-scale trading.

\section{Sampling Technique}

The population for the study comprised of all rural households in Udi local government area. A multi-stage random sampling technique was used to select the sample for the study. This sampling strategy was adopted to ensure equal chances of selecting each unit from the population being studied. The first stage involved the random selection of 10 communities out of the 24 communities in the study area. In the next stage, one village from each of the 10 selected communities was randomly selected. In the final stage, 6 households were randomly selected from each of the 10 selected villages. This gave a sample size of 60 rural households in the study area.

\section{Data collection}

Primary data for the study were collected through survey method using paper-based semistructured questionnaires and interview schedules, with the household being the unit of analysis.

\section{Data analysis}

Descriptive and inferential statistical tools such as frequency counts, percentages, four-point scale, weighted mean score, multiple regression model, T- statistics and Chi-Square were employed to analyse the data for the study. Specifically, objective I was achieved using frequency counts, percentages, T- statistics and Chi-Square. Objective II was analysed using coping strategy index and weighted mean score, while multiple regression model was used to analyse objective III.

\section{Model Specification}

\section{Coping Strategies Index (CSI)}

In analysing the extent of use of the coping strategies by these households, a coping strategy index (CSI) was developed and was ranked with the weighted mean score. The CSI gives a quantitative score for each household and is an accumulative measure of the level of coping (Orewa and Iyangbe, 2010). The extent of use of the coping strategies was expressed using a four-point scale with the scoring order 3, 2, 1, 0 for always, occasionally, rarely and never used respectively. The formula used to obtain the CSI score was adapted from Adebo and Falowo (2015) as follows:

$$
\mathrm{CSI}=\mathrm{N}_{3} \mathrm{X}_{3}+\mathrm{N}_{2} \mathrm{X}_{2}+\mathrm{N}_{1} \mathrm{X}_{1}+\mathrm{N}_{0} \mathrm{X}_{0}
$$

Where:

CSI = Coping Strategies Index

$\mathrm{N}_{3}=$ Number of households using a particular coping strategy frequently

$\mathrm{N}_{2}=$ Number of households using a particular coping strategy occasionally

$\mathrm{N}_{1}=$ Number of households using a particular coping strategy rarely

$\mathrm{N}_{0}=$ Number of households not using any of the coping strategies.

$\mathrm{X}_{3}=$ Scoring order for frequently

$\mathrm{X}_{2}=$ Scoring order for occasionally

$\mathrm{X}_{1}=$ Scoring order for rarely

$\mathrm{X}_{0}=$ Scoring order for not using any 
The CSI was used in rank order to reflect the relative position of each of the coping strategy in terms of their use.

However, the formula for calculating the weighted mean score is as follows:

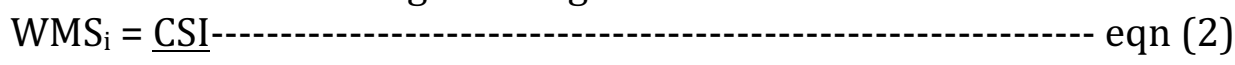

$\mathrm{Z}$

Where;

WMS $=$ Weighted Mean Score

$\mathrm{Z} \quad=$ Total number of households in the study area

$\mathrm{i}=$ Particular coping strategy used

3.5.2 Multiple Regression Model

The regression equation estimated is stated as equation (3)

$$
\mathrm{Y}=\mathrm{b}_{0}+\mathrm{b}_{1} \mathrm{X}_{1}+\mathrm{b}_{2} \mathrm{X}_{2}+\mathrm{b}_{3} \mathrm{X}_{3}+\mathrm{b}_{4} \mathrm{X}_{4}+\mathrm{b}_{5} \mathrm{X}_{5}+\mathrm{b}_{6} \mathrm{X}_{6}+\mathrm{e}_{\mathrm{i}}
$$

Where;

$\mathrm{Y}=$ Coping Strategy Index

$\mathrm{X}_{1}=$ Farm size $\{$ Hectares $\}$

$\mathrm{X}_{2}=$ Farm income $\{$ Naira $\}$

$\mathrm{X}_{3}=$ Dependency ratio (number of working members divided by the number of non-working Members)

$\mathrm{X}_{4}=$ Engagement in off-farm activities (Engaged $=1$; Not engaged $=0$ )

$\mathrm{X}_{5}=$ Marital Status (Single $=1$, Married $=2$, Widow $=3$, Widower $=4$ and separated $=5$ )

$\mathrm{X}_{6}=$ Educational level $\{$ years $\}$

$\mathrm{e}_{\mathrm{i}}=$ Stochastic error term

$\mathrm{b}_{0}=$ intercept

$b_{1}-b_{6}=$ regression coefficients of the explanatory variables

$\mathrm{X}_{1}-\mathrm{X}_{6}=$ explanatory variables

\section{RESULTS AND DISCUSSION}

Indices of rural households and socio-economic characteristics of food secure and food insecure households

Table 1. Distribution of the sampled rural households by their socio-economic characteristics and food security status

\begin{tabular}{|l|l|l|l|l|l|}
\hline Characteristics & \multicolumn{2}{|l|}{$\begin{array}{l}\text { Food secured } \\
(\mathrm{n}=25)\end{array}$} & $\begin{array}{l}\text { Food insecure } \\
(\mathrm{n}=35)\end{array}$ & \multirow{2}{*}{ P- value } \\
\cline { 2 - 5 } & Mean & $\begin{array}{l}\text { Standard } \\
\text { deviation } \\
\text { (SD) }\end{array}$ & Mean & $\begin{array}{l}\text { Standard } \\
\text { deviation } \\
\text { (SD) }\end{array}$ & \\
\hline Age & 55.28 & 13.28 & 56.91 & 13.63 & 0.645 \\
\hline Household size & 4.16 & 1.72 & 5.91 & 2.12 & $0.001^{* * *}$ \\
\hline Dependency ratio & 1.98 & 1.63 & 2.86 & 2.15 & $0.092^{*}$ \\
\hline Household income & 18360 & 10769.87 & 18314.29 & 9676.45 & 0.9863 \\
\hline Farm size & 1.14 & 0.80 & 1.61 & 1.33 & 0.117 \\
\hline Per capita income & 3646.98 & 4930.75 & 1072.63 & 339.91 & $0.003^{* * *}$ \\
\hline $\begin{array}{l}\text { Total Monthly Food } \\
\text { Expenditure }\end{array}$ & 11703.8 & 9243.52 & 6219.86 & 2835.11 & $0.002^{* * *}$ \\
\hline
\end{tabular}

Source: Survey Data, 2018

Note: ${ }^{* * *},{ }^{* *}$ and ${ }^{*}$ Significant at $1 \%, 5 \%$ and $10 \%$ level

Values are based on T-test analysis 
On the demographic and socioeconomic characteristics, the food secure and insecure households differed significantly on most of the independent variables (Table 1). The two group household significantly differed in their household size and dependency ratio at $1 \%$ and $10 \%$ significance level respectively. In general, the food insecure households were characterized by larger household size and high dependency ratio. This is not unexpected as a large number of people living in the household, would mean more competition on the available and limiting food resource. According to Feleke et al. (2003), an increase in the household size especially the non-working members put pressure on consumption than production. Also, a high dependency ratio increases the food insecurity level of the household. Furthermore, compared to the food secure households, more of the food insecure households had significantly lesser per capita income and total monthly food expenditureat $1 \%$ level of significance. This is suggestive of the fact that food insecure households earn less and therefore have constrained economic access to food.

\section{Socioeconomic characteristics of food secure and food insecure households}

Table 2. Distribution of the socioeconomic characteristics of food secure and food insecure households (Categorical variables)

\begin{tabular}{|c|c|c|c|c|c|c|}
\hline \multirow[t]{2}{*}{ Variables } & \multirow[t]{2}{*}{ Category } & \multicolumn{2}{|c|}{$\begin{array}{l}\text { Food secured \% } \\
(\mathrm{n}=25)\end{array}$} & \multicolumn{2}{|c|}{$\begin{array}{l}\text { Food insecure \% } \\
(\mathrm{n}=35)\end{array}$} & \multirow[t]{2}{*}{ P-value } \\
\hline & & Frequency & Percent & Frequency & Percent & \\
\hline Gender & $\begin{array}{l}\text { Female } \\
\text { Male }\end{array}$ & $\begin{array}{l}7 \\
18 \\
\end{array}$ & $\begin{array}{l}28.0 \\
72.0\end{array}$ & $\begin{array}{l}9 \\
26\end{array}$ & $\begin{array}{l}25.7 \\
74.3\end{array}$ & 0.844 \\
\hline $\begin{array}{l}\text { Engagement in } \\
\text { off-farm } \\
\text { activities }\end{array}$ & $\begin{array}{l}\text { No } \\
\text { Yes } \\
\end{array}$ & $\begin{array}{l}2 \\
23 \\
\end{array}$ & $\begin{array}{l}8.0 \\
92.0 \\
\end{array}$ & $\begin{array}{l}31 \\
4 \\
\end{array}$ & $\begin{array}{l}88.6 \\
11.4 \\
\end{array}$ & $0.001^{* * *}$ \\
\hline $\begin{array}{l}\text { Member of } \\
\text { Cooperatives }\end{array}$ & $\begin{array}{l}\text { No } \\
\text { Yes } \\
\end{array}$ & $\begin{array}{l}18 \\
7 \\
\end{array}$ & $\begin{array}{l}72.0 \\
28.0 \\
\end{array}$ & $\begin{array}{l}26 \\
9 \\
\end{array}$ & $\begin{array}{l}74.3 \\
25.7 \\
\end{array}$ & 0.844 \\
\hline Access to credit & $\begin{array}{l}\text { No } \\
\text { Yes }\end{array}$ & $\begin{array}{l}20 \\
5 \\
\end{array}$ & $\begin{array}{l}80.0 \\
20.0\end{array}$ & $\begin{array}{l}29 \\
6\end{array}$ & $\begin{array}{l}82.9 \\
17.1 \\
\end{array}$ & 0.778 \\
\hline $\begin{array}{l}\text { Educational } \\
\text { level }\end{array}$ & $\begin{array}{l}\text { No formal } \\
\text { education } \\
\text { Primary } \\
\text { Secondary } \\
\text { Tertiary }\end{array}$ & $\begin{array}{l}1 \\
11 \\
6 \\
7\end{array}$ & $\begin{array}{l}4.0 \\
44.0 \\
24.0 \\
28.0\end{array}$ & $\begin{array}{l}8 \\
11 \\
11 \\
5\end{array}$ & $\begin{array}{l}22.9 \\
31.4 \\
31.4 \\
14.3\end{array}$ & $0.100^{*}$ \\
\hline
\end{tabular}

Source: Survey Data, 2018

Note: ${ }^{* * *},{ }^{* *}$ and ${ }^{*}$ Significant at $1 \%, 5 \%$ and $10 \%$ level

Values are based on Chi-square analysis

Table 2 shows that there is a significant difference in the two group household (food secure and food insecure) in terms of their livelihood diversification activities and their educational attainment at $1 \%$ and $10 \%$ significance level respectively. The food secure households were engaged in other activities aside from farming to supplement farm income, thereby corroborating the food security situation of the household. Notwithstanding, in the study area, food insecure household have lesser educational qualifications than the food secure. A plausible explanation could be that educated households are more knowledgeable and as well have better food management techniques that will ensure equitable and all-round supply of food. Therefore such household is able to ensure their food security. 


\section{Household Food Insecurity Coping Strategies}

Table 3: Coping strategies adopted by rural households

\begin{tabular}{|l|l|l|l|l|l|l|l|}
\hline Coping strategies & $\begin{array}{l}\text { Frequently } \\
(3)\end{array}$ & $\begin{array}{l}\text { Occasionally } \\
(2)\end{array}$ & $\begin{array}{l}\text { Rarely } \\
(1)\end{array}$ & $\begin{array}{l}\text { Never } \\
(0)\end{array}$ & CSI & $\begin{array}{l}\text { Weighted } \\
\text { Mean Score }\end{array}$ & Rank \\
\hline $\begin{array}{l}\text { Rely on less preferred } \\
\text { and cheaper food }\end{array}$ & 47 & 10 & 1 & 2 & 162 & 2.70 & 1 \\
\hline $\begin{array}{l}\text { Restrict food } \\
\text { consumption of adults to } \\
\text { feed children }\end{array}$ & 41 & 6 & 3 & 10 & 138 & 2.30 & 3 \\
\hline $\begin{array}{l}\text { Beg or borrow food from } \\
\text { friends or relatives }\end{array}$ & 18 & 7 & 1 & 34 & 69 & 1.15 & 9 \\
\hline Buy food on credit & 24 & 5 & 3 & 28 & 85 & 1.42 & 8 \\
\hline $\begin{array}{l}\text { Reduce number of meals } \\
\text { eaten per day }\end{array}$ & 39 & 7 & 3 & 11 & 134 & 2.23 & 4 \\
\hline $\begin{array}{l}\text { Sales of asset or } \\
\text { household productive } \\
\text { resources }\end{array}$ & 15 & 1 & 1 & 43 & 48 & 0.80 & 10 \\
\hline $\begin{array}{l}\text { Limit portion size at meal } \\
\text { times }\end{array}$ & 45 & 4 & 4 & 7 & 147 & 2.45 & 2 \\
\hline $\begin{array}{l}\text { Withdrawing from } \\
\text { savings }\end{array}$ & 27 & 5 & 2 & 26 & 93 & 1.55 & 7 \\
\hline $\begin{array}{l}\text { Start other part-time } \\
\text { work }\end{array}$ & 36 & 3 & 4 & 17 & 118 & 1.97 & 5 \\
\hline $\begin{array}{l}\text { Withdrawal of children } \\
\text { from school to work on } \\
\text { farm or elsewhere }\end{array}$ & 29 & 9 & 2 & 20 & 105 & 1.75 & 6 \\
\hline
\end{tabular}

Source: Field Survey Data, 2018

The coping strategies to household food insecurity were measured on a four point scale; frequently, occasionally, rarely and never used (Table 3). Generally, about 10 different coping strategies were very prominent among the available strategies employed. The study indicates that relying on less preferred and cheaper food was ranked first (2.70) among the coping strategies. This finding is common to that of Akerele et al., (2013), who found this strategy, the most commonly practised among rural households in South west Nigeria. The high rate of use of this strategy in the study area could be linked to the high market price of basic foodstuffs as a result of the current economic recession in the country. The low income of the households compared to high food prices, forces households to resort to the consumption of less preferred food such as eating wild fruits or less quality food or buying the type of food (regardless of the quality) that the available cash within the household can afford just to make sure that there is food on their table. Suggesting that majority of the household when faced with food deficit situation, consume compromising and socially unacceptable food, with less concern about the nutrient and health issues associated with the consumption of such food.

The second-ranked strategy (2.45) adopted by households was limiting portion size at meal times. This coping strategy is in consonance with the findings of Orewa and Iyangbe (2010), who reported that rural households in Edo state Nigeria start to limit or ration their food intake (consumption soothing) when faced with food shortage. Furthermore, the third-ranked strategy was restricting food consumption of adults to feed children (2.30), while the fourthranked was reducing the number of meals eaten per day (2.23). It was gathered from the interview schedule that at the initial stage of food shortage, the adults reduce the quantity of 
food they eat so that their younger children can have food to eat and in cases when food shortage becomes extensive they are further forced to cut down on the number of meals eaten per day. Hence, instead of the three-square meal households are forced to either have just two meals or one in worst cases. Consequently, suggesting that food insecurity situations alter the consumption pattern of the rural dwellers or force them into unfavourable dietary adjustment. Meanwhile, the least ranked coping strategy utilized was selling off their asset or household productive resources (0.80). By implication, in the event of food deficit, the last thing that comes to the mind of the majority of the sampled household is to start selling their assets or possessions. Moreover, such coping strategy is described as a negative mechanism, having long-term detrimental effect on household food security. Therefore, it is not surprising that such strategy was amongst the least to be considered by the households in the face of adversities.

\section{Factors influencing the use of multiple Coping Strategies}

Table 4: Multiple regression result of the factors influencing the Coping Strategies employed by the households

\begin{tabular}{|l|l|l|l|l|}
\hline Explanatory Variables & Coefficient & Std. Error & T value & Sig. \\
\hline (Constant) & 3.978 & .173 & 22.950 & .000 \\
\hline Farm Size & .001 & .033 & .042 & .967 \\
\hline Farmers' Income & $-.356^{* * *}$ & .053 & -6.677 & .000 \\
\hline Dependency Ratio & $.056^{* * *}$ & .019 & 3.023 & .004 \\
\hline Engagement & -.035 & .075 & -.467 & .642 \\
\hline Marital Status & $-.081^{*}$ & .045 & -1.816 & .075 \\
\hline Educational Level & $-.543^{* * *}$ & .087 & -6.279 & .000 \\
\hline $\begin{array}{l}\text { R }=0.837 \\
\text { S. Error }=0.274\end{array}$ & & & & \\
F - Ratio = 131.701 & & & & \\
Sig. $=0.001$ & & & & \\
\hline
\end{tabular}

Source: Computer analysis of multiple regression model, 2018

*Significant at $10 \%,{ }^{* * *}$ Significant at $1 \%$

In order to identify the socio-economic characteristics of the farmers that influence households' use of multiple coping strategies, some household socio-economic variables were subjected to regression analysis. The four functional forms were estimated and the linear function was the chosen as the lead equation. It had the highest coefficient of multiple determination $\left(\mathrm{R}^{2}\right)$ value $84 \%$ and also the highest value of $\mathrm{F}$-calculated 131.701 .

The result in table 4 shows that farmers' income, marital status and educational level negatively influence the number of coping strategy adopted in the study area while the dependency ratio was positively significant.

The individuals' income was negative and highly significant at $1 \%$ level. This implies that as the individuals' income increases by 1 naira, the coping strategies adopted will be reduced by $36 \%$. This is not unexpected, as household's income is considered an essential factor determining household access to food, especially during periods where household farm produce is limited. Hence, high income level's is expected to boost household's food availability and access to sufficient quantity and good quality food. Thus, reducing the number of coping strategies employed. 
Dependency ratio was positive and highly significant at $1 \%$ level. By implication, the more the number of non- working member in the household, the number of coping strategies adopted increases by $6 \%$. As there are more household members who cannot fend for themselves and rely on other working household members for their food needs. There are fewer income streams and constrained economic access to sufficient food. Therefore such household is compelled to take multiple strategies to cope with food deficit situation.

Marital status was negative and significant at $10 \%$. The more the widow, widower and divorced who have nobody to depend on or fall back on in terms of food resource shortage, the more the coping strategy adopted to cope with food insecurity and adversities. Furthermore, the educational level was negative and highly significant at $1 \%$. This indicates that the more educated the farmer is, the less likely he adopts multiple food insecurity coping strategies by $54 \%$. Thus insinuates that education plays a role in addressing the food security situation of the households. As noted by FAO (2012), lower educational levels deter access to better job opportunities in the labourmarket and impede more profitable entrepreneurship. Furthermore, an educated household head is in a position to comprehend novel information, effectively and efficiently utilize available resources and more likely to adopt innovations aimed at enhancing their food security.

\section{SUMMARY AND CONCLUSION}

The study analysed the strategies used by the rural households to cope with food insecurity in Udi local government area of Enugu state. Households were grouped based on their food security status. The two group (food secure and food insecure) households differed significantly in terms of their livelihood diversification activities, educational attainment, household size, dependency ratio, per capita income and monthly food expenditure. This study result is in concordance with the findings of prior work, showing that the coping strategies employed by the vulnerable households were not mutually exclusive, rather a mixed approach comprising multiple strategies was adopted.

These strategies provide households with short-term food availability and help them maximize utilization of available food for the period while they go through food shortage. The most employed coping strategies by the household were adjudged not detrimental to their livelihoods and future food security, indicating their resilience to income shocks. Income, marital status and educational level negatively influence the number of food insecurity coping strategies adopted in the study area while the dependency ratio was positively significant. By implication, the necessity for the use of multiple food insecurity coping strategies among the sampled households reduces with less dependency ratio, improved income and higher educational qualification of the household head. Also whether a household head is married significantly reduced the number of coping strategy employed by households.

\section{RECOMMENDATIONS}

While agriculture may play a major role in the reduction of food insecurity, the food insecurity problem in Nigeria cannot be solved by promoting agriculture alone. Attention should also be given to the promotion of non-farming activities among smallholder farming household. A strategy that emphasises the strengthening of farm and non-farm linkages is likely to yield better results in terms of employment and income generation, thus reducing the number reliant and non-working household members. Poverty alleviation programs geared at enlightening households on how to boost their income by harnessing all economic and livelihood opportunities in the rural area is recommended. 
Furthermore, education for the rural dwellers is equally important. Transition support from food assistance and poverty alleviation program to education promotion among the rural households could as well be a viable solution out of food insecurity. There is the need for adult learning targeted at the rural households. In addition, given that farming is the main economic base in the area under study, the state government should enact appropriate policies to promote the potentials of the rural households. Such households should be provided with agricultural inputs such as improved planting materials and fertilizers at affordable rates. Soft loans at reduced interest prices should be made available and accessible to the rural households at the time of need so that they are encouraged to scale up their production. Hence, boosting their productivity and income level and consequently their food security status.

\section{ACKNOWLEDGMENT}

The authors will like to thank the University of Exeter and Commonwealth Scholarship for providing support for this study.

\section{References}

Adebo G.M. \& Falowo, O.O. (2015). Rural Household Food Security and Coping Strategies in SouthWest, Nigeria: A Gender Differentials Perspective. Food Science and Quality Management, Vol. 14, pp. 44 - 49.

Akerele D, Momoh S, Aromolaran A, Oguntona C, \& Shittu M. (2013). Food Insecurity and coping strategies in South-West Nigeria. Food security Vol. 3, pp. 407-414.

Akinyele, I. (2009). Ensuring food and nutrition security in rural Nigeria: An assessment of the challenges, information needs, and analytical capacity. Nigeria strategy support program background paper No. NSSP 007, International Food Policy and Research Institute (IFPRI).

Amaza, P., Umeh, J., Helsen, J. \& Adejobi O (2006). Determinants and measurement of food insecurity in Nigeria: some empirical policy guide. International association of agricultural economists' annual meeting, August: 12-18.

Edeh, H. \& Gyimah-Brempong, K. (2015). Determinants of change and household responses to food insecurity: Empirical evidence from Nigeria. African Journal of Agricultural Research, Vol 10, No. 5, pp. 423-433.

Ehebhmen, O, Obayelu, A, Vaughan, I, \& Afolabi, W. (2017). Rural household's food security status and coping strategies in Edo state Nigeria. International Food Research Journal, Vol 1, No. 333-340.

Ehui, S. \& Tsigas, M. (2009). “The role of Agriculture in Nigeria's Economic Growth: A general Equilibrium Analysis" A paper presented at the International Association of Agricultural Economist, Beijing, China.

Ezeama, N. Ibeh, C. Adinma, E., Emelumadu, O. \& Adogu, P. (2015). Coping with Household Food Insecurity: Perspectives of Mothers in Anambra State, Nigeria. Journal of Food Security, Vol 3, No. 145-154.

Ifeoma, I., \& Agwu, A. (2014). Assessment of food security situation among farming households in rural areas of Kano state, Nigeria. Journal of central European agriculture, Vol. 15, No. 1.

Food and Agriculture Organization of United Nations, FAO (2012). The State of Food Insecurity in the World 2012 Key messages W. and I. 2012. FAO, ed., Rome: FAO, WFP and IFAD. 2012.

Farzana, F. D., Rahman, A. S., Sultana, S., Raihan, M. J., Haque, M. A., Waid, J. L., Ahshanul, H., Jillian, L., Nuzhat, C., Tahmeed, A. (2017). Coping strategies related to food insecurity at the household level in Bangladesh. PLoS ONE $12: 4$.

Fasinmirin, J., \& Braga, F. (2009). Agriculture for sustainable food, energy and industrial development in the SubSaharan Africa: The case of Nigeria. African Journal of Food Science, Vol. 13, No. 429-433.

Feleke, S., Kilmer, R. L., Gladwin, C. (2003). Determinants of Food Security in Southern Ethiopia. A selected paper presented at the 2003 American Agricultural

Economics Association meetings in Montreal. Canada. Retrieved on 12th December, 2005. http://ageconsearch.umn.edu/bit stream/22010/1/sp03fe02.pdf.

Kabubo-Mariara, J., \& Kabara, M. (2014). Climate change and food security in Kenya. Paper submitted for CSAE conference.

Liwenga, E. (2003) Food insecurity and coping strategy in semi-arid area: the case of Mvumi in central Tanzania. PhD. thesis submitted to the department of Human Geography, University of Stockholm.

Maxwell, D. \& Caldwell. R. (2008). The Coping Strategies Index Field Methods Manual. 
Maxwell, D., Levin, C., Armar-Klemesu, M., Ruel, M., Morris, S. \& Ahiadeke, C. (2000). Urban livelihoods and food and nutrition security in Greater Accra, Ghana. Washington, DC: International Food Policy Research Institute.

National Population Commission (2006). Housing and population census, 2006. Abuja. http://ghdx.healthdata.org/record/nigeria-population-and-housing-census-2006.

Ojo, E. \& Adebayo, P. (2012). Food security in Nigeria: an overview. European Journal of Sustainable Development, Vol, 2, No. 199-221.

Orewa, S. I. \& Iyangbe, C. (2010). The struggle against hunger: The victims and the food security strategies adopted in the adverse condition. World Journal of Agric. Sciences, Vol, 6, No. 740-745.

Wolfe, W. \& Frongillo, E. (2001). Building household food-security measurement tools from the ground up. Food and Nutrition Bulletin 1: 5-12.

World Bank (1986). Poverty and hunger: issues and options for food security in developing Countries. Washington DC, USA: Word Bank. 